\title{
The Research of the Reform and Mode of Local Higher Fashion Design and Engineering Education which Service Industry Development ${ }^{*}$
}

\author{
Bingqiang TIAN, Shouzhong HU \\ Shanghai University of Engineering Science
}

\begin{abstract}
This article is based on the relationship between development of creative industry and regional demand of talent structure in Shanghai and analysis the mode of Institute of fashion education in Shanghai University of Engineering Science reform and the realization. The conclusions are that should form an effective way of innovative talent training; comply with the strategic planning of the development of creative industries in Shanghai; locate in the direction of "combination of art and engineering" talents training, adhere to the theory of combining teaching philosophy and practice, creativity and technology, heritage and transcendent; etc.
\end{abstract}

KEYWORD: costume creative industry; talent training; reform of teaching

\section{PREFACE}

Shanghai garment industry is developing from the past simply sample processing to creative design and brand marketing with Shanghai industrial structure optimization and adjustment and the development of Shanghai textile industry to the direction of stylish, high-end and innovative. So there is a higher demand to education location and training model of Shanghai local universities' "applying" complex costume talent. But it is still a short history for the local higher costume education of stressing the educate feature that based on the local economic development and forming the "applying" talent education system. That is why there are several problems about that. For example, the Shanghai local higher costume education exist the following problems: School level is not clear; Training objectives are not clear; Curriculum System lack of practicality; Incompatible with the business needs; Teaching mode, train positioning defects; the level of teachers is low and "double tutors" lack of ability; it is difficult to find jobs for graduates and they switch jobs frequently; etc. The problems make us to focus on the reform of local higher costume education. Recently, Shanghai Municipal Education Commission (Shanghai SMEC NO.20124), whose "Views on the part of the undergraduate majors of warning in 2012" reviews that Shanghai has entered a critical moment of the innovation-driven and transformation of productive mode.

The existing part of Shanghai higher education majors are disharmony with the demand of the reconstruction of the Shanghai industry. As Colleges and universities are the highlands of talent, knowledge of the city, the reform of Shanghai local higher apparel education system imminent. Education reform should make a difference.

\section{THE RELATIONSHIP BETWEEN DEVELOPMENT OF APPAREL CREATION INDUSTRY AND REGIONAL DEMAND OF TALENT STRUCTURE}

\subsection{The influence of Shanghai textile industry structural adjustment to personnel training}

Textile was once the iconic traditional industries in Shanghai. Shanghai Textile Industry Bureau used to have 462 enterprises and over 50 million textile workers. However, as an international metropolis, Shanghai cannot accommodate a backward traditional labor-intensive industry. Thus, in 1992 Shanghai textile started the industrial structure adjustment and re-layout. So far, the number of 50 million textile workers has been cut to be reduced to1.8-2 million, but the Shanghai textile still occupies an important position in Shanghai's economy. The Shanghai Textile Holding (Group) Corporation is one of the largest conglomerates in

* This work is supported by Shanghai Municipal Education Commission (ZZGJD12017, B14035) 
Chinese textile industry, which ranks at the position of China500 enterprises 231. With the data analysis, Shanghai textile output value is more than 830 billion in 2010, which is doubled than the foregone 40 billion Yuan of Shanghai Textile Industry Bureau output value. The total revenue has reached 361 billion, which is a 67.7 percent growth over 2005 . The profit growth is 5 times than it used to be. Shanghai is the largest textile import and export trade port in China at present, accounting for $39 \%$ of the national import and export volume of textile. Shanghai is also the largest textile consumer market in china, whose value is more than 500 billion a year. From the view point of industrial structure, Shanghai textile industry structure has gone through the period of optimization, which has a completely industrial chain of apparel creative industries cluster. Shanghai has the textile industry structure which is supported by three pillars of a large clothing, large decorative and industrial textiles. At the same time, "12th Five-Year Plan" of Shanghai textile industry has proposed the path to advanced textile with method of technology and fashion.

Although Shanghai has the country's most renowned Donghua University and other local colleges such as Shanghai University of Engineering Science, Shanghai Institute of Visual Art and many Sino-foreign cooperative school, but the existing personnel training size and structure still cannot meet the demand of the adjusting apparel and creative industries for the trend of developing creative industry and optimizing the textile industry in Shanghai. It is a serious structurally deficient of suitable talent. According to the incomplete statistics of recent years, the clothing graduates each year have a $50 \%$ diverted rate. It is indeed a huge loss. Above all, there are existing gaps between higher costume education and the demand of enterprises to different extents.

\subsection{Forecast of the quantity and structure of Shanghai apparel and creative industries demand for talent.}

We should give comprehensive and objective attention to the needs of the Shanghai garment creative design and engineering of integrated talent. Fuse apparel and creative industries characteristics with the planning of local clothing higher education scale and professional structure to reform local higher clothing education mode, so as to form characteristics position through reasonable positioning.

Depending on the number of demand for Shanghai apparel and creative industries development. According to the conventional clothing business marketing talent demand structure, technical personnel accounting for $15 \%$ (of which the designers accounted for $6 \%$ of the total accounted for $45 \%$ of technology staff, marketing staff accounted for 13 percent, managers accounted for $36 \%$ ). Depending on this, it is possible to predict the scale of the needs of the creative talent (Designers, craftsmen, pattern makers, managers and senior professionals engaged in clothing research and development) in the garment industry personnel structure. If depend on the fact that Shanghai Textile Holding Group Company employees have over 2 million, the group's production accounted for 1.63 percent of the city's proportion, it is the conclusion that Shanghai will need clothing creative industry talent and the scale of demand is probably more than 20 million, including design and technology close to over 10 million. According to an annual rate of teaching and graduate at the rate of $3-5 \%$, then in accordance with the training scale and speed conveyor graduates in recent years, Donghua University (Accounted for the larger the proportion of senior personnel of the National Research) and Shanghai University of Engineering Science of Clothing Institute, Shanghai Visual Arts College (They are the two major local universities to cultivate a professional clothing talent), cannot meet the demand in the period of " $12^{\text {th }}$ five year" in Shanghai demand for creative industry talent. So there is a great demand and developing space of Shanghai higher apparel education.

Depending on the structure of the Shanghai apparel creative industries of the demand for talent. Talent has the character of comprehensive knowledge; since the knowledge structure of the talent of apparel business is simple and has a narrow range of knowledge, thus it is difficult to adapt to the comprehensive quality demand of our manpower needs of apparel and creative industries such as artistic, scientific, applications, production, economy. Fashion design education should not only attach importance to the style of clothing design, color design, graphic design and the other educations, we also should pay attention to grasp the requirements of modern clothing production technology, clothing materials, engineering and technical applications. Market economy forced the apparel design teaching pay more attention on fashion trend forecasting, brand marketing and ecommerce management skills. Such as creative development team of corporation: brand director, designer, design assistant, jewelry designer; corporate positions including: fashion design, the plate division, Merchandiser, fabric sourcing, sales manager, brand management and the production manager and other positions.

Creative industries require expertise knowledge and major structure, which is closely related to the training mode and major direction of local higher education. thus how to learn the advanced experience of foreign fashion design education, to reform the old ways of teaching, which truly reflect 
the relationship between art, engineering, and marketing elements to make the clothing of higher education to take the initiative to adapt the regional apparel development of creative industries, whose task is extremely arduous and urgent to Shanghai garment higher education.

\section{THOUGHTS ON INSTITUTE OF FASHION EDUCATION OF SHANGHAI UNIVERSITY OF ENGINEERING SCIENCE REFORM AND THE REALIZATION MODE}

Institute of Fashion Design of Shanghai University of Engineering Science depends on the characteristic of fashion design and engineering and creative design, engineering, technology. On the other hand, brand marketing Penetrate each other to realize mutual penetration, coordinated development. Institute of Fashion Design has taken great efforts to form the chain of the "fashion creative design clothing engineering - brand fashion show". As a local university that is mainly conveying the talents of designers, engineers and marketers for the Shanghai (partly for the nationwide) apparel and creative industry, Institute of Fashion Design of Shanghai University of Engineering Science has developed the total size of the graduates and the employment situation each year with development of creative industry in Shanghai (Chart1,2). Part of the major enrollment ratio is rising rapidly, such as fashion design and engineering, fashion design and engineering (garment CAD / CAM), which reflects the talent training direction meet the needs of Shanghai's industrial restructuring development. But there are changes in the specific majors whose enrollment ratio is steady declined and business needs. It shows that the direction of running of the Institute of Fashion Design is in line with the needs of the Shanghai economy, but the scientific structure and professional direction needs to be adjusted. The application of talent training model has to be reformed (In Chart).

Table 1. University of Engineering Science Enrollment Statistics of Fashion major in 2007- 2011

\begin{tabular}{|c|c|c|c|c|c|}
\hline Start year & 2007 & 2008 & 2009 & 2010 & 2011 \\
\hline major enrollment & Total & Total & Total & Total & Total \\
\hline Fashion Design and engineering & 53 & 54 & 49 & 78 & 82 \\
\hline (other provinces) & 2 & 7 & 15 & 46 & 58 \\
\hline Art design(Clothing and decorative) & 57 & 75 & 83 & 68 & 62 \\
\hline (other provinces) & 0 & 16 & 17 & 15 & 20 \\
\hline Textile engineering & 61 & 59 & 51 & 51 & 55 \\
\hline (other provinces) & 9 & 20 & 26 & 31 & 38 \\
\hline Fashion Design and engineering (garment CAD/CAM) & 25 & 24 & 22 & 25 & 41 \\
\hline (other provinces) & 0 & 5 & 8 & 15 & 15 \\
\hline marketing(garment marketing) & 65 & 59 & 68 & 54 & 59 \\
\hline (other provinces) & 2 & 6 & 30 & 23 & 21 \\
\hline Art design(Fashion show planning & 20 & 20 & 29 & 21 & 23 \\
\hline (other provinces) & 7 & 9 & 19 & 13 & 18 \\
\hline total & 294 & 345 & 398 & 427 & 474 \\
\hline
\end{tabular}

Table 2. Statistics of graduates' employment signing rate of Fashion major in 2007-2011.

\begin{tabular}{|c|c|c|c|c|c|}
\hline year & 2007 & 2008 & 2009 & 2010 & 2011 \\
\hline Fashion Design and engineering & & 81.0 & 96.0 & 97.9 & 80.8 \\
\hline Art design(Clothing and decorative) & & 94.0 & 91.2 & 88.0 & 74.1 \\
\hline Textile engineering & & 94.0 & 80.0 & 76.3 & 82.3 \\
\hline Fashion Design and engineering(garment CAD/CAM) & & 94.0 & 100.0 & 100.0 & 79.1 \\
\hline marketing(garment marketing) & & 77.0 & 80.7 & 86.7 & 77.9 \\
\hline Fashion show planning & & 70.0 & 83.3 & 89.4 & 60.0 \\
\hline total & 62.2 & 86.0 & 88.1 & 88.2 & 77.2 \\
\hline
\end{tabular}




\subsection{The idea of composite talent education suitable for apparel and creative industries demand process model}

The concept of combining art and engineering application personnel. Fashion design and textile Engineering Institute of University of Engineering Science changed its name for the purpose of adapting Shanghai textile industry's trend of stylish, high-end, innovative restructuring and development, which changed the nature of academic courses. Changing From a simply engineering institute to a mixture of engineering and art high lightened the direction of application of the "fashion industry" creative talents. The institute has four departments: fashion design, fashion design and engineering, garment $\mathrm{CAD}$, textile engineering (It May be imprecise of the name of reflecting the fashion discipline, teaching content and direction of personnel training), which based on principle of "disciplines chain docking industrial chain". Combining the nature of the acquirements of Shanghai fashion industry for talent and the nature of fashion design and according to the combination of concept design and the reality design, creative arts and technological innovation, art and engineering technology, art design and computing technology, which can gradually adjust and improve teaching objectives of education programs and combined with the application of art and engineering talent.

Talents training objectives of the specific compound of "Art combined with engineering". Emphasis on theory and practice. In the Personnel training programs and teaching programs, change too much emphasis on theoretical knowledge and design to express in the past to strengthen on the hands of practical ability. Emphasis on creativity and technology. To break the past curriculum fragmentation can form the mode of containing fabrics and accessories design, garment production process, technology, visual performances city planning, and retail brand marketing ---- which is a kind of "creative design" and "subject" teaching mode. Emphasis on Heritage and beyond. Adhering to the combination of Chinese and Western culture and carrying forward the combination of traditional costumes and modern fashion innovation to realize the mode of fashion design and education.

\subsection{Teachers of adapting to the trend of combining arts and engineering complex talent for apparel and creative industries}

In the teaching of "combining art and engineering", the key is to form a reasonable teacher structure and teachers' interdisciplinary and the quality training of double tutors. As the historical reasons (The predecessor of the Institute is the branch of the East China Institute of Textile), the Faculty Academic Affiliation, the subject structure is irrational. Lack of discipline "hybrid". It is very bad that the textile courses "mold" constantly "Copy" and piled up a collection of teachers for art and engineering which combined with the complex student professional training. The lack of cross-innovation has made too much classmates under the same tutelage and lead the result of "homogeneity". Teaching and academic disciplines colliding with each other and inspire each other is bad for "art and engineering combining" of innovative thinking and education. Teachers of the "homogeneity", whose existence of informal organization is not conducive to unity and cooperation, work ethic, dedication, impact teaching and research resources effectively. Therefore, teacher learning edge "hybrid" is conducive to interdisciplinary innovation and discipline professional development.

In the "art and engineering combining" education, education mode should be placed on the "Double Type" quality training. Specialized courses teachers should study in business and office and participation in the actual management and operation, which can improve the technology and practice ability. So that they have both a solid theoretical foundation and a higher level of classroom teaching, but also has a wealth of application skills, and practical work experience. Changing the fact that young teachers are probably not less than $50 \%$ proportion (the reasons for the history of the establishment of the institute lead the young teachers have a larger proportion); it is difficult to complete the design work production process of their own. Such as practice fashion design courses, if not dependent on the experimental teachers assisted instruction, then it is difficult to independently complete teaching for ordinary teachers. Institute must follow the route of the "industrial school", with the high quality social resources, that is, the Shanghai Textile Holding (Group) Company, Shanghai Textile Research Institute and other high-tech enterprises. It is also important to adhere to the cooperation of industryuniversity joint schools, and part of expert teachers, to employ a certain proportion of joint teacher, mentor to improve the teacher structure so as to form a team of optimized teaching team, to meet the "art and engineering combination" of teaching, research, design projects and professional construction support target.

\subsection{Teaching channels of "art and engineering combination" and applied talents which is suitable for the garment industry needs}

Creative design teaching "subject" should be: students. Change the traditional teacher-centered indoctrination teaching methods, but to greater use of research teaching methods and "to teach, learn, do----integration "teaching methods to enable students to actively participate in teaching, and 
character to stimulate divergent thinking. For example, the most prominent characteristic of the teaching methods of the French Fashion Institute of IFM the its main job is not to give lectures, but the organization of teaching. Their contents of each chapter have to hire related businesses full-time staff or senior professor on the podium and speaker teachers to engage in dialogue and students to engage in dialogue, questions and to exchange. Until the end of the course, teachers organize students to groups in team to participate in lectures of expert company to research the destination to write a variety of practical report. For example, in the Lectra held the International Symposium of "personnel training of Lectra software of teaching applications in 2011", Netherlands and Denmark Institute of Fashion Design introduced that their third and fourth grade students learn to master basic knowledge of fashion design in the classroom (such as with the "Lectra design software"), which can be fully applied in practice. Under the help of teacher, they service such as "LV" well-known brands, offer design works, and provide part of the commercialization of teaching cases. "Studentbased, practice" fashion design and engineering course teaching is an effective channel for teaching fashion design, production technology, marketing and other work of art engineering talent.

Creative talent training "mode" should be: innovative studio teaching and the subject for practice. To realize the combination of theory and practice, promotion of technology and teaching to each other, the interactive process of indoor and outdoor teaching. According to the student's preferences and strengths, schools help students find quickly their own potential for developing which aspect, so as to stimulate students' enthusiasm and initiative by an ideal model of personality development to make their own timber. Institute encountered in a lot of problems in the process to explore the studio teaching model and implementation of "art and engineering combination" teaching mode. Such as studio teaching model may be limited to the school's human, financial resources, so the Institute must rely on social resources through industry-university cooperation. On the basis of cooperating with Shanghai Textile Holding Co., Ltd. Textile Research Institute, Tahui knitted garments company, Heng Yuan Xiang enterprise and so on for such a long time, established various forms of internal and external joint studio platform for the service of "art and engineering combination" education mode. Because for group system, sub system, major system, etc. school system in the form, complete credit system meet mostly to the needs of the studio model.

\section{CONCLUSIONS}

In the Shanghai textile and apparel and creative industries' "12th Five-Year Development Plan", which said the concept of technology and fashion, the path of high-end textile and focusing on the development of new functional chemical fiber and materials for products, famous brands of textile production and trading and the fashion industry, so as to strive to scale of operation into the top three Chinese textile and garment industry, the first of the total exports of Chinese textile and apparel industry. Under the new situation of Shanghai's industrial restructuring, the garment industry has become an important branch of the creative industry and the fashion industry is taking shape. On the other hand, a great creative talent demand has opened up space for developing the higher education of Shanghai local fashion design and engineering.

University of Engineering Science's fashion and apparel education should grasp the opportunity to achieve the goal of innovative teaching reform: To form an effective way of innovative talent training, to comply with the strategic planning of the development of creative industries in Shanghai; locate in the direction of "combination of art and engineering" talents training, adhere to the theory of combining teaching philosophy and practice, creativity and technology, heritage and transcend; to innovate creative studio teaching model, to take the mode of project courses teaching system, improve the standard of "double tutor" to stimulate students' enthusiasm for learning, and get the knowledge of design and garment effectively; to carry out industryuniversity cooperation, unite campus and off-campus teaching resources to promote the joint teaching mechanism effectively. Therefore, this could make the Shanghai local higher fashion design and engineer education reform service in Shanghai creative industry structure optimization and adjustment of demand for talent to realize common development and benefit.

\section{REFERENCES}

[1] Lideyi The status research of garment industry and garment Higher Education of Shandong Jinan Textile 2010 (1).

[2] Chen Dongsheng Gan Yingjin Analysis of the art engineering fashion and garment design talent training mode and target Teach of Chinese University 2010(2). 